\title{
Schamberg Disease / Progressive Purpuric Dermatosis - Diagnosis and Management Challenges
}

\author{
LOREDANA ELENA STOICA*, ALINA MARIA VILCEA', RUCSANDRA CRISTINA DASCALU², RALUCA NICULINA CIUREA ${ }^{3}$, \\ RADU DIACONU ${ }^{4}$ \\ 'University of Medicine and Pharmacy of Craiova, Department of Dermatology, 2-4 Petru Rares Str., 200349, Craiova, Romania \\ 2Emergency Hospital Targu Carbunesti, Department of Dermatology, 5 Eroilor Str., 215500, Targu Carbunesti, Romania \\ ${ }^{3}$ University of Medicine and Pharmacy of Craiova, Pathology Department, 2-4 Petru Rares Str., 200349, Craiova, Romania \\ 4 University of Medicine and Pharmacy of Craiova, Department of Pediatrics, 2-4 Petru Rares Str., 200349, Craiova, Romania
}

\begin{abstract}
Schamberg disease, also called progressive pigmented purpuric dermatitis is a rare disease characterized by pigmentary, non-palpable, progressive lesions with symmetrical distribution on lower extremities with vasculitic appearance. The etiology of this disease is unknown. Schamberg disease is still considered idiopathic, without an established therapy. Given the fact that this disease has many recurrences, management and treatment is a challenge for the dermatologist.
\end{abstract}

Keywords : Schamberg disease, erythrocyte extravasation, remission, flares

Pigmented purpuric dermatoses are a group of chronic skin disorders with unknown etiology and pathogenesis, characterized by symmetrical rash, formed by petechiae and pigmentary macules, localized on the lower limbs.

The clinical aspectis due to capillary fragility with erythrocyte extravasation at the skin level or hemosiderin deposition. The histopathological features are lymphocytic perivascular infiltrate and endothelial edema [1-3].

Schamberg disease (SD) has chronic, progressive evolution and the clinical findings can disappear within a few days, remaining colour changes depending on hemosiderin degradation.

Treatment is sometimes ineffective and recurrences are not uncommon [4-7]. There are cases reports [8,9], in medical literature, who had good response to colchicine after six months of treatment and also variable results are obtained with griseofulvin, oral corticosteroids, pentoxifylline, topical corticosteroids, skin emollients and PUVA [10-13].

\section{Experimental part}

Case report

First case is of an 21 years old female patient, who was adFirst case is of an 21 years old female patient, who was admitted in Dermatology department of University Hospital Craiova, for multiple erythematous, reddish-brown, purpuric patches on the lower limbs with symmetrical distribution (fig.1,2). Lesions were not itchy and the patient related their presence from about 2 days.

The rash has first started 2 years ago, had remissions and flares and the patient was treated with desloratadine. Past medical history was negative for other diseases.

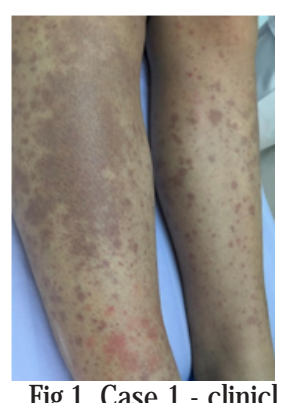

Fig.1. Case 1 - clinic aspects

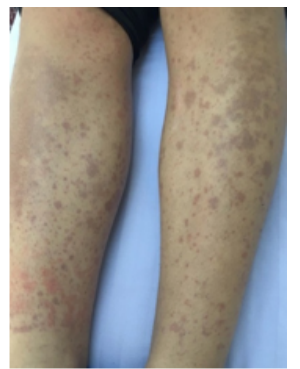

Fig.2. Case 1-clinical aspects
Clinical examination showed BMI $=21.2$ and Fitzpatrick's phototype III.

Laboratory findings were in normal limits.

Skin lesion biopsy with histopathologic examination showed: orthokeratosis in the epidermis, acanthosis and papilomatosis (fig.3). In the dermis, extravasated red cells, capillary fragility, perivascular inflammatory cells, mostly lymphocytes with rare PMN (fig.4).

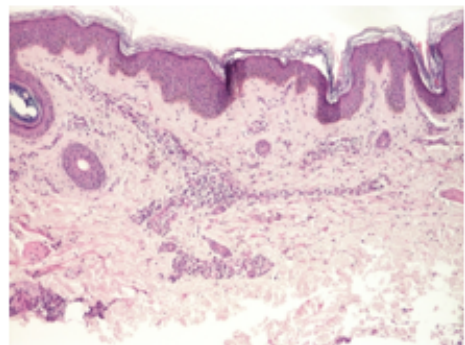

Fig.3. Orthokeratosis in the epidermis, acanthosis and papilomatosis; perivascular inflammatory cells in dermis, col HE x20

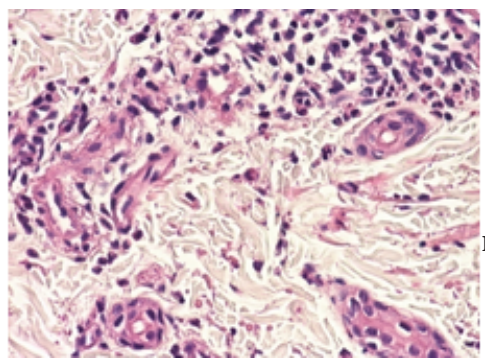

Fig.4. In the dermis, extravasated red cells, capillary fragility, perivascular inflammatory cells, mostly lymphocytes with rare PMN, COl HE x 200

Based on clinical examination, medical history, laboratory findings and histopathological examination we established the diagnosis of Schamberg disease.

Treatment was represented by systemic corticosteroids (methylprednisolone $16 \mathrm{mg}$ daily, for 7 days and dose decrease with $4 \mathrm{mg}$ every two days), pentoxifylline $400 \mathrm{mg}$ twice daily, topical betamethasone cream daily. The response to treatment was good and the rash was healed after 10 days.

Second case is of an 82 years old female patient, from urban areas, that was admitted in Dermatology department of University Hospital Craiova for reddish, purpuric isolated macules and patches that were intensely itchy and were located on the lower extremities (fig.5,6). The rash has appeared 7 days ago. The patient related the debut of the

* email: tanaseloredanaelena@yahoo.com, Phone: +4072285739 5 All authors contributed equally to this paper. 
disease 1 year ago and an evolution with remissions and flares. On past medical history, patient had hypertension and in 2009 had suffered a cerebral artery stroke.
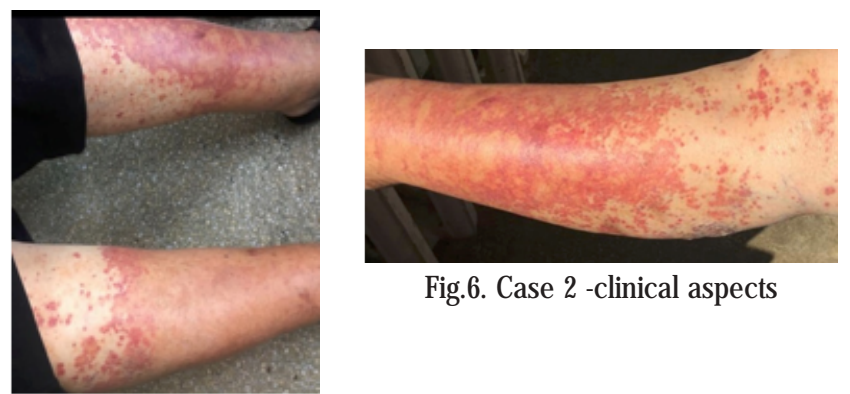

Fig.6. Case 2 -clinical aspects

Fig.5. Case 2 -clinical aspects

At clinical examination we found $B M I=29.1$, Fitzpatricks's phototype III, mild arthralgia at mobilisation. Laboratory findings were in normal limits.

Skin lesion biopsy and histopathological examination reveals in epidermis atrophy with orthokeratosis, discrete spongiosis and rare erythrocytes in the tissue (fig.7); in the dermis numerous extravasated erythrocytes, inflammatory cells (lymphocytes), oedema [14,15] and collagen fibres degeneration (fig.8).

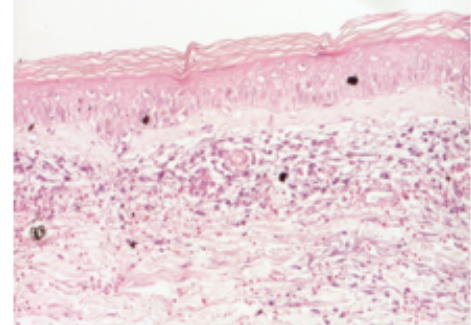

Fig.7. In epidermis atrophy with orthokeratosis, discrete spongiosis and rare erythrocytes in the tissue, perivascular inflammatory cells, col HE x 40

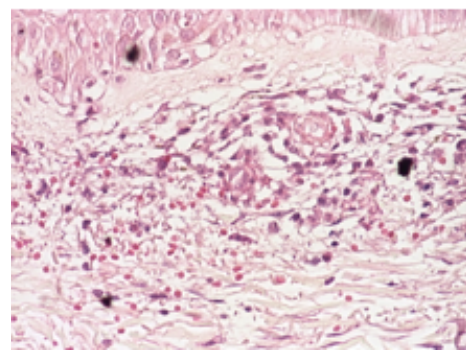

Fig.8. In the dermis numerous extravasated erythrocytes, inflammatory cells (lymphocytes), col HE $\times 200$

After clinical examination, laboratory findings and histopathological examination we established the diagnosis of Schamberg disease.

Treatment was represented by methylprednisolone 16 $\mathrm{mg}$ daily for 7 days and dose decrease with $4 \mathrm{mg}$ every two days, pentoxifylline $400 \mathrm{mg}$ twice daily, rupatadine $10 \mathrm{mg}$ daily and topical steroid cream daily. The response to treatment was favorable, with improvement of the lesions aspect.

\section{Results and discussions}

Schamberg disease, also called progressive pigmented purpuric dermatitis is a rare disease characterized by pigmentary (reddish-brown), non-palpable, progressive lesions with symmetrical distribution on lower extremities with vasculitic appearance. The disease has been described for the first time by Jay Frank Schamberg in 1901. Lesions are usually asymptomatic and can arise at any age group. Age of patients varies from 11 to 66 years. SD was the commonest in males between 21 to 40 years [12,16]. Family history of SD was present in three cases which has also been reported earlier $[17,18]$.

The etiology of SD is unknown. There are studies where are reported that hypertension, venous stasis, exercise, capillary fragility, focal infections, alcohol ingestion and several drugs are important trigger factors for SD [1,12,19].

Pathogenesis is related to capillary fragility and erythrocytes extravasation due to inflammation and cell-mediated immunity produced by T lymphocytes.

Several drugs can trigger pigmentary and purpuric dermatoses like acetaminophen, aspirin, carbamazepine, furosemide, infliximab, amlodipine, interferon and thiamine.

Patients with SD usually have normal laboratory findings $[20,21]$ with normal coagulation tests.

Another factor that might be responsible in the etiopathogenesis of SD is contact allergy. The patch test results were found to be relevant in some case reports on SD [22]. There are case reports were venous insufficiency and hyperlipidemia are the basic predisposing factors in SD [1]. A 13year old boy presented with SD in an unusual zosteriform distribution. He recently has taken methylphenidate which has not been described as a cause of SD [23].

The lesions initially occur in the lower limbs, but may arise in any area of the body. The disease has a chronic course, with new lesions succeeding the old ones that slowly present bleaching $[4,18,24,25]$. Pigmented purpuric dermatoses commonly manifests as pigmented spots bilaterally. In most cases, the rash is symmetrical, petechial and macular, but in same cases can appear telangiectasias, red, brown or yellow patchy pigmentation. Unilateral presentation was found in two cases [26].

\section{Differential diagnosis} like:

Should consider other pigmented purpuric dermatoses

Pigmented purpuric lichenoid dermatosis of Gougerot and Blum: is characterised by purpuric lesions with slow onset and progressive evolution and symmetrical distribution on the legs and tights. After years of evolution, lesions have lichenoid aspect.

Majocchi disease (purpura annularis telangiectodes): clinical findings are represented by purpuric macules with centrifugal progression, ring-shape with telangiectasia and achromatic and atrophic centre. After few months of evolution, lesions spontaneously involve.

Bateman purpura: seen in elderly patients, lesions develop on upper extremities and legs, and are usually related to menopause and andropause.

Dermite-ocre Favre-Chaix: is seen in patients with chronic venous insufficiency and lesions are represented by brownish macules and patches on the legs.

Other diseases that should be considered for differential diagnosis are contact dermatitis, vasculitis, mastocytosis and livedo reticularis.

\section{Treatment}

SD is still considered idiopathic, without an established therapy. Given the fact that this disease has many recurrences, management and treatment is a challenge for the dermatologist.

A food diet without allergenic products (chocolate, spices, coffee, alcohol) is recommended. Physical effort, hypothermia and trauma should be avoided. Chronic infections, endocrinological diseases should be treated because they can be an aggravating factors for SD.

Systemic and topical corticosteroids are effective for SD. Prolonged led dependency must be avoided and over-warming also. The patients should elevate legs during rest and avoid prolonged standing, wearing tight shoes and shocks in hot humid climate [18].

Other drugs used are griseofulvin, ascorbic acid, calcineurin-inhibitors, colchicine, pentoxifyline, immunosupressants. Photodynamic therapy and laser therapy are also effective. [27,28]. 
To date, there is no proven effective treatment, but there is general agreement regarding the use of anti-inflammatory drugs to treat skin diseases with immune mediation $[4,12,29,30]$.

\section{Prognosis}

Schamberg disease has an evolution with remission and flares. Lesions may persist and extend with time and eventually resolve spontaneously. There are no systemic findings associated.

\section{Conclusions}

Schamberg disease etiology and pathogenesis still remains uncertain, with chronic evolution and challenging treatment and management.

\section{References}

1.GONUL, M., KULCU CAKMAK, S., OZCAN, N., OGUZ, I.D., GUL, U., $B$ BYYKLI, Z. Clinical and laboratory findings of pigmented purpuric dermatoses. Ann Dermatol. 2014;26:610-614.

2.BERCEANU, C., PAITICI, S., BERCEANU, S., BRATILA, E., OFITERU, A.M., MEHEDINTU, C., BERBECE, S.I., NAVOLAN, D., OBLEAGA, C.V. BALSEANU, A.T., Rev. Chim. (Bucharest), 69, no. 8, 2018, p. 2245-2250 3.BERCEANU, C., CIUREA, E.L., CIRSTOIU, M.M., BERCEANU, S., OFITERU, A.M., MEHEDINTU, C., BERBECE, S.I., CIORTEA, R., STEPAN, A.E., BALSEANU, A.T., Rev. Chim. (Bucharest), 69, no. 9, 2018, p. 23962401

4.CAVALCANTE, M.L, MASUDA, P.Y., BRITO, F.F., PINTO, A.C.V.D., ITIMURA, G., NUNES, A.J.F. Schamberg's disease: case report with therapeutic success by using colchicine. An Bras Dermatol. 2017 Mar-Apr; 92(2):246-248.

5.BERBECE, S.I., CONDRATOVICI PLESEA, A., PAVEL, L.L., GRIGORE, A.C., Rev. Chim. (Bucharest), 68, no. 5, 2017, p. 1075-1076

6.DINU, A.C., BRUJBU, I., CERGHIZAN, D., BULIMAR, V., MACOVEI, L.A., BOTEZATU, D. Rev. Chim. (Bucharest), 67, no. 6, 2016

7.GURAU, G., DINU, A.C., EARAR, K., VOICU, D.C, BOTEZATU, D. Rev. Chim. (Bucharest), 67, no. 3, 2016

8.FILIP, I.C., BERBECE, S., RADUCU, L., FLORESCU, I.P., ARDELEANU, V., JECAN, C.R., Mat. Plast., 54, no. 3, 2017, p. 414-417

9.MACOVEI, L.A., CRISTESCU, V., DEBITA, M., DINU, A.C. Rev. Chim. (Bucharest), 68, no. 10, 2017

10.GELLER, M. Novo tratamento bem-sucedido da púrpura de Schamberg com colchicina. Einstein. 2004;2:2067-2067.

11.GELLER, M. Benefit of colchicine in the treatment of Schamberg's disease. Ann Allergy Asthma Immunol. 2000;85:246-246.

12. SARDANA, K., SARKAR, R., SEHGAL, V.N. Pigmented purpuric dermatoses: an overview. IntJ Dermatol. 2004;43:482-488. 0

13.J ECAN, C.R., NICOLAU, A., FLORESCU, I.P., ARDELEANU, V., BERBECE, S., Mat.Plast., 54, no. 1, 2017, p. 88-90
14.TITIUCA, C., DINU, A.C., ALEXA, I.A., PRUNA, R., LUCA, M.C., DOROBAT, C., VATA, A., LUPOAE, M. Rev. Chim. (Bucharest), 67, no. 5, 2016

15.RAFTU, G., DEBITA, M., DINU, A.C., PANGAL, A.,HODOROG, D., CUCIUREANU, D.I. Rev. Chim. (Bucharest), 70, no. 1, 2019

16.TRISTANI-FIROUZI, P., MEADOWS, K.P., VANDERHOOFT, S. Pigmented purpuric eruptions of childhood: A series of cases and review of literature. Pediatr Dermatol. 2001;18:299-304.

17.SETHURAMAN, G., SUGANDHAN, S., BANSAL, A., DAS, A.K., SHARMA, V.K. Familial pigmented purpuric dermatoses. J Dermatol. 2006;33:63941.

18. SHARMA, L., GUPTA, S. Clinicoepidemiological study of pigmented purpuric dermatoses. Indian Dermatol Online J. 2012;3:17-20.

19.LIN, W.L., KUO, T.T, SHIH, P.Y., LIN, W.C., WONG, W.R., HONG, H.S. Granulomatous variant of chronic pigmented purpuric dermatoses: report of four new cases and an association with hyperlipidaemia. Clin Exp Dermatol. 2007;32:513-515.

20.ARDELEANU, V., BERBECE, S.I., FLORESCU, I.P., JECAN, C.R., Mat. Plast., 54, no. 1, 2017, p. 37-40

21.BERBECE, S., ILIESCU, D., ARDELEANU, V., NICOLAU, A., JECAN, C.R. Rev. Chim. (Bucharest), 68, no. 7, 2017, p. 1438-1441

22.LAZAROV, A., CORDOBA, M. The purpuric patch test in patients with allergic contact dermatitis from azo dyes. Contact Dermatitis 2000;42:23-26.

23.BABILAS, P., ROESCH, A., SZEIMIES, R.M., LANDTHALER, M., VOGT, T. Zosteriform pigmented purpura of Schamberg: case report and differential diagnosis of zosteriform skin lesions J Dtsch Dermatol Ges. 2004 Nov; 2(11):931-4

24.ANGELESCU, D., ANGELESCU, T., SIMU, M.D., MUNTEAN, A., MESAROS, A.S., BERBECE, S., ALB, S. Rev. Chim. (Bucharest), 70, no. 10, 2019, p. 3649-3653

25.SCHAAS, B.A., IVAN, S., TITIANU, M., CONDRATOVICI, C.P., MAIER, A., SCHAAS, C.M. Mat. Plast., 54, no. 1, 2017, p. 133-136

26.TAKETUCHI, Y., CHINEN, T., ICHIKAWA, Y., ITO, M. Two cases of unilateral pigmented purpuric dermatosis. J Dermatol. 2001;28:4938.

27.OKADA, K., ISHIKAWA, O., MIYACHI, Y. Purpura pigmentosa chronica successfully treated with oral cyclosporin $\mathrm{A}$. Br J Dermatol. 1996 Jan. 134(1): 180-1.

28.TAMAKI, K., YASAKA, N., OSADA, A. ET AL. Successful treatment of pigmented purpuric dermatosis with griseofulvin. $\mathrm{Br}$ J Dermatol. 1995 Jan. 132(1): 159-60.

29.BALAN, G., PELIN, A.N., MACOVEI, L.A., CONDRATOVICI, A.P., CONDRATOVICI, C.P., BUSILA, C. Rev. Chim. (Bucharest), 68, no. 3, 2017, p. 6008-6011

30. PAVEL, L.L., TITIUCA, C., BERBECE, S., PLESEA, A.P. Rev. Chim. (Bucharest), 68, no. 5, 2017, p. 1095-1097

Manuscript received: 10.07.2019 